\author{
Riccardo Campa \\ Uniwersytet Jagielloński
}

\title{
ROBOTY SPOŁECZNE I PRACA SOCJALNA
}

\section{Abstract \\ Social Robots and Social Work}

The goal of this article is to seek a path of cooperation between engineers and sociologists in view of the construction of increasingly sophisticated social robots. First, I show how humanoid and animaloid companion robots are used in the field of applied sociology and social work. Secondly, I explore several problems relating to social robotics, and in particular those of effectiveness and safety of human-robot interaction. Finally, I emphasize that two key concepts in this research area are scenario and persona. Trained sociologists and psychologists may give a substantive contribution to the development of social robotics by helping engineers in the creation of scenarios and personas.

Key words: social robots, social work

\section{Wstęp}

Społeczne konsekwencje robotyki zależą w dużym stopniu od tego, jak ludzie wykorzystują roboty, oraz od tego, jak rozwija się robotyka z technicznego punktu widzenia. Dlatego właśnie dla inżynierów skłonnych do współpracy z socjologami pomocne mogłoby być zapoznanie się z problemami pracy socjalnej i innych usług społecznych. Z kolei socjolodzy zainteresowani społecznymi aspektami robotyki mogliby skorzystać, przyglądając się bliżej technicznym aspektom robotów nowej generacji.

Niestety, ani inżynierowie nie mają zwyczaju regularnie czytać literatury socjologicznej, ani socjolodzy i pracownicy socjalni z reguły nie są na bieżąco z publikacjami inżynierów. W niniejszym artykule próbuję złamać tę niepisaną zasadę, pozwalając sobie na analizę literatury $z$ obu tych dziedzin.

Tego typu interdyscyplinarne podejście jest szczególnie potrzebne po upowszechnieniu się tak zwanych „społecznych robotów”. Ich ogólna definicja przedstawiona została przez badaczkę społeczną Kate Darling (2012: 4):

Robot społeczny to materialnie wcielony, autonomiczny aktant, który komunikuje się i wchodzi $\mathrm{w}$ interakcje z człowiekiem na poziomie emocjonalnym. (...) Ważne jest, aby odróżnić społeczne roboty od nieożywionych komputerów, jak również od robotów przemysłowych i usługowych, które 
nie są zaprojektowane po to, aby oddziaływać na ludzkie uczucia i naśladować społeczne sygnały. Ponadto roboty społeczne postępują zgodnie z zasadami zachowań społecznych, mają zróżnicowane „stany umysłu” oraz przystosowują się do tego, czego nauczyły się poprzez interakcje.

Darling wylicza przykłady robotów społecznych, w tym interaktywne zabawki-roboty, takie jak Baby Alive My Real Babies wyprodukowane przez Hasbro; towarzysze domowi, jak pies AIBO marki Sony, robot-dinozaur Pleo firmy Jetta oraz robot nowej generacji NOA autorstwa Aldebaran; terapeutyczne zwierzątka, jak mała foczka Paro oraz roboty Kismet, Cog i Leonardo Instytutu Technologicznego w Massachusetts (MIT). Jak widać, roboty społeczne w większości przypominają ludzi (humanoids) bądź zwierzęta (animaloids). Ich postać ma fundamentalne znaczenie, ponieważ funkcją robotów społecznych jest interakcja z ludźmi na poziomie emocjonalnym, a ten typ interakcji zasadza się na wizualnej i dotykowej percepcji w nie mniejszym stopniu, niż na werbalnej komunikacji.

Wykorzystanie zwierzęcokształtnych robotów do pocieszania i zabawiania samotnych, starszych osób zdążyło już wywołać etyczną debatę. Robert Sparrow (2002), w swoich rozważaniach na temat produkcji i marketingu robotów domowych, takich jak choćby produkowany przez firmę Sony mechaniczny pies AIBO, stwierdził, iż użycie robo-towarzyszy jest pomysłem chybionym i nieetycznym. Dzieje się tak dlatego, że właściciele robotów, by czerpać korzyści z interakcji z nimi, muszą się niejako okłamywać co do natury relacji, która łączy ich z przypominającymi zwierzęta domowe maszynami. Jeśli by przyjąć poszukiwanie prawdy w otaczającym nas świecie za etyczny imperatyw, wówczas zarówno zachowanie projektantów oraz konstruktorów robotów towarzyszących, jak i ich odbiorców, czyli osób, które pozwalają sobie na tego typu fałszywy sentyment, należałoby uznać za nieetyczne.

Russell Blackford (2012) nie zgadza się z powyższą konkluzją, twierdząc, że do pewnego stopnia dajemy się zwodzić fałszywemu sentymentalizmowi w codziennym życiu, a ten w ograniczonym zakresie, jest do pogodzenia ze zwyczajną uczciwością i z dążeniem do prawdy. Innymi słowy, Blackford nie przeczy twierdzeniu, jakoby szukanie prawdy było moralnie szlachetne, zaznacza natomiast, że należałoby uwzględnić pewne kategorie wyjątków.

Roboty domowe jako część terapii pacjentów z demencją mogłyby stanowić takie odstępstwo. W przypadku leczenia osób dotkniętych demencją najważniejsze jest stymulowanie ich oraz angażowanie, a nie podawanie im obiektywnej wizji rzeczywistości. Głównym zadaniem pracownika socjalnego w pracy $\mathrm{z}$ tego typu chorymi jest pomoc w komunikowaniu emocji, redukowanie lęku oraz poprawa nastroju, a to może zostać osiągnięte przy użyciu zwierzęco- lub ludzkokształtnych robotów (Odetti i in. 2007; Moyle i in. 2013).

Znaczenie społecznych robotów nie powinno być bagatelizowane, szczególnie przez socjologię stosowaną. W krajach zaawansowanych technologicznie rozpoczął się już proces robotyzacji pracy socjalnej. Przykładowo coraz częściej używa się robotów do opieki nad osobami starszymi. Jest to konsekwencja dwóch innych powiązanych z sobą procesów: $\mathrm{z}$ jednej strony zmian demograficznych, które przyspieszają starzenie się 
populacji i wpływają na zwiększające się zapotrzebowanie na personel opieki społecznej, $\mathrm{z}$ drugiej zaś postępów w technologii stwarzających innowacyjne możliwości radzenia sobie z tymi problemami. Priska Flandorfer (2012) podkreśla że „w dzisiejszych czasach technologie asystujące pozwalają osobom starszym na dłużej zachować niezależność w swoich domach. Formy pomocy obejmują rozwiązania od teleopieki i smart homes, przez czynne systemy usług i roboty domowe aż po wspieraną przez roboty terapię oraz roboty pomagające w sytuacjach społecznych. Systemy nadzorujące potrafią wykryć upadek osoby, sprawdzić ciśnienie krwi, rozpoznać poważne problemy z oddychaniem czy pracą serca i natychmiastowo ostrzec opiekuna".

Mimo panującej tendencji do przypisywania fizycznego wsparcia maszynom, a psychologicznej pomocy pracownikom socjalnym „z krwi i kości”, ten sztywny podział zaciera się w przypadku robotów społecznych opiekujących się osobami starszymi. Flandorfer (2012) zauważa, że „roboty interaktywne współpracują z ludźmi poprzez komunikację dwukierunkową i zapewniają osobistą pomoc w codziennych czynnościach, takich jak przypominanie osobom starszym o zażyciu lekarstwa, przygotowanie jedzenia, spożywanie posiłku i mycie się. Tego typu urządzenia technologiczne współpracują z personelem pielęgniarskim i członkami rodziny w tworzeniu systemu wsparcia dla osób starszych, oferując emocjonalną i fizyczną pomoc".

Roboty społeczne są specjalnie zaprojektowane do pomocy ludziom nie tylko w pracy socjalnej, lecz również w innych dziedzinach. Jednym z głównych źródeł informacji o trendach w robotyce jest seria wydawnicza Springera pod redakcją Bruna Siciliano i Oussamy Khatiba. Jak Siciliano (2013: v) zauważył, „robotyka jest w trakcie wielkiej transformacji swoich celów i zakresu. $\mathrm{Z}$ dominującego nastawienia przemysłowego robotyka szybko wkroczyła w środowisko ludzkie i dynamicznie stworzyła w nim nowe wyzwania. Oddziałując z ludźmi, wspomagając ich i służąc im, pojawiające się roboty wpłyną na ludzi i ich życie”. Siciliano spostrzegł, że największe wyzwania pojawiają się na skrzyżowaniu dyscyplin. Rozwój robotyki nie wpływa tylko na same roboty, ale także na inne dyscypliny naukowe. Jednocześnie dyscypliny te wpływają na domenę robotyki. Biomechanika, technologia haptyczna, symulacja wirtualna, animacja, chirurgia i sieci sensorowe (sensor networks) są kilkoma przykładami dyscyplin, które stymulują rozwój robotyki, a zarazem czerpią z niej. Wymieńmy szczegółowo parę przykładów.

\section{Efektywność i bezpieczeństwo interakcji między człowiekiem a robotem}

W 2013 roku czterech inżynierów - Jaydev P. Desai, Gregory Dudek, Oussama Khatib i Vijay Kumar - wydało książkę pod tytułem Experimental Robotics, zbiór esejów $\mathrm{z}$ „13th International Symposium on Experimental Robotics”. Teksty te koncentrują się na zagadnieniu interakcji i kooperacji między ludźmi oraz robotami i stwierdzają, że efektywność i bezpieczeństwo tej współpracy może zależeć od rozwiązań technicznych, takich jak użycie sztucznych mięśni pneumatycznych (Daerden, Lefeber 2014). 
Ponadto każde urządzenie techniczne ma swoje zalety i wady. Na przykład jedno może przodować w efektywności, a tracić w zakresie bezpieczeństwa, i odwrotnie (Shin i in. 2013: 101-102).

Innym problemem technicznym, który rodzi oczywiste konsekwencje etyczne i społeczne, jest kwestia bezpieczeństwa. Inspirującą książką na ten temat jest Towards Safe Robots: Approaching Asimov's 1st Law (2014) Sami Haddadina. Autor wyróżnia dwie główne dziedziny w ramach interakcji człowiek-robot: (1) poznawcze i społeczne interakcje człowiek-robot (cHRI) oraz (2) fizyczne interakcje człowiek-robot (pHRI). cHRI definiuje jako domenę, która łączy tak różne dyscypliny, jak psychologię, nauki kognitywne, relacje człowiek-komputer, czynniki ludzkie i sztuczną inteligencję z robotyką. Poznawcze interakcje człowiek-robot dążą do zrozumienia społecznych i psychologicznych aspektów możliwej interakcji między ludźmi i robotami oraz dążą do odkrycia jej podstawowych aspektów. Z kolei pHRI „zajmuje się fizycznym problemem interakcji, szczególnie z perspektywy projektowania i kontroli robotów. Skupia się na realizacji tak zwanych robotów przyjaznych człowiekowi przez połączenie podejścia bottom-up właściwego actuation technologies z zaawansowanymi algorytmami kontroli, generatorami ruchu reaktywnego, i algorytmami planowania drogi w celu osiągnięcia bezpiecznych, intuicyjnych i wysoce wydajnych schematów interakcji fizycznych" (Haddadin 2014: 7).

Bezpieczeństwo oczywiście nie jest nowym problemem w robotyce ani w naukach inżynieryjnych. Stało się głównym zagadnieniem w pHRI, odkąd stała interakcja fizyczna zyskała na ważności. W przeszłości inżynierowie przeważnie przewidywali rozwój ciężkich robotów przemysłowych przy względnie niewielkiej fizycznej interakcji człowiek-robot. Większość robotów zdolnych do autonomicznego poruszania się w środowisku i interakcji z człowiekiem była mała, zbyt powolna, przewidywalna i niedojrzała, aby móc spowodować jakiekolwiek zagrożenie dla ludzi. W konsekwencji rozwiązanie było dość proste: segregacja.

Powszechnie uznawano, że standardy bezpieczeństwa wymagają, aby przestrzeń pracy ludzkiej była oddzielona od przestrzeni pracy robotów. Współcześnie sytuacja zmieniła się. Jak zauważył Haddadin (2014: 7), „,ze względu na kilka przełomów w projektowaniu i kontroli robotów, pierwsze starania ostatnio podjęte polegały na skoncentrowaniu się na środowisku przemysłowym i rozważaniu bliskiej współpracy między człowiekiem i robotem. Wymusza to fundamentalnie odmienne podejścia i działania w celu określenia nowych standardów właściwych dla uregulowania interakcji człowiek-robot (Human-Robot Interaction- HRI)". Przełomy te, w szczególności rozwój cHRI otworzyły droge dla nowych poddyscyplin, czy - jeśli ktoś woli - nowej dziedziny interdyscyplinarnej: robotyki społecznej. Wbrew temu, że nazwa sugeruje pewną hybrydę między naukami społecznymi i inżynieryjnymi, obecnie ta subdyscyplina uprawiana jest głównie przez inżynierów, jakkolwiek o „humanistycznej” wrażliwości.

Warto pamiętać o tych aspektach, zwłaszcza że często technofile i technofobowie mają skłonność do przewidywania fantastycznych bądź katastroficznych scenariuszy rozwoju robotyki, bez rozważania długiej i intensywnej pracy w jej zakresie, która już się dokonała 
i która jest przed nami. Jest jeszcze wiele małych problemów, takich jak te związane ze wspominanymi PAMs (SMP), które muszą zostać rozwiązane, zanim będziemy mogli zobaczyć NDR-114 z filmu Bicentennial Man czy wyglądające jak terminator maszyny chodzące po ulicach.

\section{Roboty niewielkich rozmiarów}

Nie oznacza to, że literatura science fiction nie może być źródłem pomysłów dla robotyki. Wystarczy popatrzeć na przykład kolejnego kierunku rozwoju robotyki, jakim jest domena małych i bardzo małych maszyn automatycznych, takich jak miliroboty ${ }^{1}$, mikroroboty i nanoroboty. Roboty te wchodzą w interakcję z ludźmi w zupełnie inny sposób niż makroskopijne roboty społeczne.

W serii Siciliano i Khatiba znajdziemy interesującą książkę Small-Scale Robotics. From Nano-to-Millimeter-Sized Robotic Systems and Applications pod redakcją Igora Paprotny'ego i Sarah Bergbreiter $(2014)^{2}$.W „Przedmowie” redaktorzy wyjaśniają wpływ science fiction na robotykę: „W filmie z 1968 roku The Fantastic Voyage zespół naukowców zostaje zredukowany do minimalnych rozmiarów i odbywa fascynującą podróż w ludzkim ciele, wchodzi w interakcje z ludzką mikrobiologią w celu usunięcia niedającego się zoperować guza. Dzisiaj grupa specjalistów od robotyki usiłuje zbudować system małych robotów, które być może pewnego dnia będą mogły w rzeczywistości wejść w interakcję z ludzką mikrobiologią".

Te małe roboty nazywane są „robotami małej skali”. Ich rozmiar wynosi od kilku milimetrów do kilku nanometrów. Mają liczne zastosowania, między innymi w produkcji, medycynie czy w działaniach poszukiwawczych i ratowniczych. Mimo to krok, który dzieli nas od wyobraźni do realizacji, od science fiction do nauki, nie jest mały. Pozostaje wiele wyzwań, takich jak produkcja tego typu robotów, sterowanie nimi czy źródła ich energii.

Inżynierowie regularnie porównują zdolności systemów robotycznych obejmujących roboty małej skali z biologicznymi systemami podobnej wielkości i często znajdują inspiracje w biologii, kiedy usiłują rozwiązać problemy techniczne w takich dziedzinach, jak nawigacja czy zachowania interaktywne (Floreano, Mattiussi 2008: 399-514; Liu, Sun 2012; Wang, Tan, Chew 2006).

Celem badań nad robotami małej skali jest często dorównanie, a ostatecznie przekroczenie zdolności systemów biologicznych o tych samych rozmiarach. Autonomiczne systemy biologiczne milimetrowych rozmiarów (jak mrówki czy muszki owocowe) są zdolne do odczuwania, kontroli i ruchu, co umożliwia im funkcjonowanie w nieustrukturyzowanym środowisku i wykonywanie tak

\footnotetext{
${ }^{1}$ Milirobot to neologizm utworzony $\mathrm{z}$ angielskiego słowa millirobot.

${ }^{2}$ Książka zawiera wybrane teksty oparte na prezentacjach $\mathrm{z}$ The Different Sizes of Small-Scale Robotics: from Nano-, to Millimeter-Sized Robotic Systems and Applications przedstawionych na International Conference on Robotics and Automation (ICRA 2013), Maj 2013, Karlsruhe, Niemcy.
} 
złożonych zadań, jak poszukiwanie pokarmu, mapowanie czy gromadzenie się. Mimo że systemom robotycznym milimetrowej skali nadal brakuje złożoności ich biologicznych konkurentów, postępy w ich produkcji i w zakresie zintegrowanych technologii stale zbliżają ich zdolności do tych posiadanych przez systemy biologiczne (Paprotny,Bergbreiter 2014: 9-10).

Aktualnie zdolności systemów mikrorobotycznych są ciągle dalekie od tych, które charakteryzują systemy biologiczne o mikrorozmiarach. Rzeczywiście, „systemy biologiczne są zdolne do wysoce autonomicznych zachowań przy rozmiarach rzędu kilkuset mikrometrów. Na przykład, liczące $400 \mu \mathrm{m}$ roztocza kurzu mogą autonomicznie poruszać się w celu poszukiwania pokarmu i pokonywania wysoce nieustrukturyzowanych środowisk. Podobne zdolności posiadają Amobeaproteus czy Dicopomorpha zebra" (Paprotny, Bergbreiter 2014: 9-10).

W przeciwieństwie do systemów biologicznych systemy mikrorobotyczne mają zaledwie ograniczoną autonomię, ponieważ brakuje im niezależnej kontroli oraz własnego źródła energii. Pomimo różnic między systemami biologicznymi i robotami małej skali inżynierowie nie godzą się na przegraną. Myślą raczej, że te luki podkreślają ważne obszary badań, ukazując poziom autonomii, który powinien być osiągalny dla systemów robotycznych wszystkich rozmiarów (Paprotny, Bergbreiter 2014: 10-11).

Twierdzenia te wyrażają optymistyczne mniemania inżynierów.

\section{Od nawigacji i manipulacji do interakcji}

W swojej książce Human-Robot Interaction in Social Robotics (2013) Takayuki Kanda i Hiroshi Ishiguro wyjaśniają dość dobrze naturę zmiany paradygmatu, która dokonała się przy przechodzeniu od robotów przemysłowych do interaktywnych. Przypominają, że do niedawna robotykę charakteryzowały dwa główne nurty badawcze: nawigacja i manipulacja. Pierwsza z nich jest domeną autonomicznych robotów mobilnych. Robot „obserwuje środowisko za pomocą kamer i skanerów laserowych i buduje model środowiska. Dzięki niemu planuje przemieszczanie się z punktu startowego do docelowego" (Kanda, Ishiguro 2013: 1).

Innym nurtem wczesnej robotyki była manipulacja, wykorzystywana na przykład w badaniach nad ramionami robotów. Podobnie jak ramię ludzkie, ramię robota jest często złożone i wymaga wyrafinowanego algorytmu planowania ruchu. Obecnie istnieje wiele przemysłowych zastosowań nawigacji i manipulacji, a innowacje ostatnich dekad zrewolucjonizowały tę dziedzinę. Dwie różne dyscypliny akademickie przysłużyły się do rozwiązania problemów z nawigacją i manipulacją: sztuczna inteligencja i robotyka sensu stricto.

Według Kandy i Ishiguro (2013: 1-2) robotyka współcześnie musi zająć się nowym polem badawczym: interakcją. „Robotyka przemysłowa opracowała komponenty kluczowe dla budowania robotów humanoidalnych, jak czujniki i silniki. W latach 1990-2000 
firmy japońskie stworzyły różne, imitujące zwierzęta i ludzi, roboty. Sony zbudowało robota-psa AIBO i QRIO, który jest małym robotem antropomorficznym, Honda opracowała imitującego dziecko robota ASIMO, a Mitsubishi Heavy Industries Ltd. zaprojektowało Wakamaru. Niestety, Sony i Mitsubishi Heavy Industries Ltd. wstrzymały swoje projekty, ale Honda nadal je kontynuuje. Celem tych firm było opracowanie interaktywnych robotów (...)".

Rosnąca liczba robotów mobilnych zdolnych do wykonywania zadań wymagających wchodzenia w interakcje z ludźmi uzasadnia znaczenie robotyki społecznej. Co więcej, interakcje człowiek-robot staną się powszechne. Firmy japońskie pracują nad humanoidami i androidami z mocnym przekonaniem, że te maszyny, o ludzkim wyglądzie, mogą zastąpić najbardziej naturalnych partnerów komunikacyjnych człowieka, to znaczy innych ludzi. Na przykład zaprojektowano kobietę-robota, która wita odwiedzających targi gości i odpowiada na ich pytania w kilku językach (Arkin 1998).

Jak zauważają Kanda i Ishiguru (2013: 5), najmocniejszy powód uzasadniający ten program tkwi „we wrodzonej ludzkiej zdolności do rozpoznawania ludzi i preferowania interakcji ludzkich. Ludzki mózg nie reaguje emocjonalnie na widok sztucznych obiektów, takich jak komputery czy telefony. Posiada on jednak wiele skojarzeń z ludzką twarzą i możliwości pozytywnego reagowania wskutek tego podobieństwa”.

\section{Scenario i persona: problemy interakcji werbalnej}

Wygląd jest jednym z problemów związanych ze społeczną akceptacją robotów. Interakcje słowne są równie istotne. Bilge Mutlu i in. wydali niedawno książkę Social Robotics (2011), która ukazuje interesujący rozwój w kierunku ulepszonego $\mathrm{HRI}^{3}$. W jednym z tekstów Złotowski, Weiss i Tscheligi wyjaśniają naturę tej dziedziny badawczej i planowaną metodologię. Podkreślają, że „szybki rozwój systemów robotycznych, który obserwujemy w ostatnich latach, pozwala naukowcom na badanie HRI w miejscach innych niż pomieszczenia fabryczne. Roboty są używane w centrach handlowych, na dworcach kolejowych, szkołach, na ulicach i w muzeach. Wkraczając do środowiska ludzkiego, projektowanie HRI ostatnio zwróciło się od jedynie technologicznych zastosowań do podejścia ukierunkowanego na użytkownika" (Złotowski i in. 2011: 1-2).

Rzeczywiście, badacze pracują nad projektem Interactive Urban Robot (IURO), który tworzy robota zdolnego do nawigowania w środowisku ludzkim za pomocą informacji uzyskiwanych od napotkanych pieszych.

3 Tom zawiera wystąpienia $\mathrm{z}$ trzeciej International Conference on Social Robotics (ICSR) w Amsterdamie, Holandia, 24-25 listopada 2011. Równie interesujące są tomy związane z wcześniejszymi i późniejszymi konferencjami. Por. GeShuzhi i in. 2010; GeShuzhi i in. 2012; Hermann i in. 2013. 
Dwa kluczowe pojęcia w tych badaniach to scenario i persona ${ }^{4}$. Te narzędzia już są dość popularne w ramach interakcji człowiek-komputer (HCI). Obecnie podejście to adaptowane jest do HRI. „Scenarios to historie narracyjne składające się $\mathrm{z}$ jednego bądź więcej aktorów z celami i różnymi przedmiotami, których używają do osiągnięcia tych celów. Zazwyczaj aktorzy w scenariuszach zwani są personas. Ich głównym celem jest zapewnienie, że produkt jest zaprojektowany dla konkretnych użytkowników, a nie abstrakcyjnego, nieistniejącego "przeciętnego użytkownika«. Często więcej niż jedna persona jest tworzona w celu imitowania całego spektrum grupy docelowej" (Złotowski i in. 2011:3).

Interesującym aspektem robotyki społecznej jest konieczność zaadaptowania przez badaczy - nawet, jeśli są pierwotnie wykształceni jako inżynierowie - społecznej czy psychologicznej perspektywy w celu tworzenia osób. Wynika to z tego, że proces tworzenia osób rozpoczyna się od rozpoznania kluczowych aspektów demograficznych danej populacji. W przypadku wspomnianego powyżej przykładu dotyczy to szczególnie pieszych. W badaniach nad interakcjami robot-pieszy badacze analizowali zawód, wykształcenie, wiek i zdolności językowe wybranych pieszych i zdobywali kolejne informacje w trakcie rozmów $\mathrm{z}$ nimi; ,informacje te zostały wzbogacone przez dane uzyskane $\mathrm{w}$ trakcie wywiadów, podczas których pytaliśmy uczestników, dlaczego podchodzili do wybranych pieszych. Nic dziwnego, że jednym z najważniejszych czynników stanowiących o sukcesie interakcji była kwestia, czy osoba była miejscowa, czy nie" (Złotowski i in. 2011: 4).

Nietrudno przewidzieć, że wraz z powstawaniem coraz bardziej zaawansowanych robotów, wzrastać będzie zapotrzebowanie na systematyczną pomoc wyszkolonych socjologów i psychologów w celu "tworzenia” personas i scenarios oraz „uczenia” humanoidów, jak zachowywać się w różnych środowiskach. Innymi słowy, coraz częstsza interakcja między mobilnymi robotami i ludźmi toruje drogę dla wzmożonej interakcji między robotyką społeczną (badaniami inżynierów nad HRI) i socjologią robotów (badaniami socjologów nad społecznymi aspektami robotyki).

\section{Wnioski}

Socjologowie analizują to, co się dzieje, dlaczego tak się dzieje oraz starają się przewidzieć, jakie mogą być scenariusze przyszłości. Jak już to wyjaśnił Max Weber (2008: 40-46), nie naszym zadaniem jest mówić, czy to, co się dzieje, lubimy lub też nie. Co więcej, szczególnie wydaje się to jałowe, jeśli przedmiotem analizy jest automatyzacja. Świat nieustannie się zmienia. Od początku rewolucji przemysłowej wiele sektorów gospodarki zostało zautomatyzowanych. Wiele zawodów i stanowisk pracy zniknęło, a inne

${ }^{4}$ Scenario i persona to terminy angielskie używane przez Złotowski'ego, Weissa, Tscheligi (2011), których autor postanowił nie tłumaczyć. W innych badaniach użyto odmiennych terminów: script i actor (Schank, Abelson 1975). 
będą zanikać w przyszłości, czy tego chcemy, czy nie. Wielu intelektualistów wyrażało niechęć do rewolucji przemysłowej w ciągu ostatnich dwóch stuleci, ale te negatywne osądy nie zmieniły trendu. Pozostają one w literaturze jako pewne źródło informacji autobiograficznych.

Proces automatyzacji wiąże teraz sektor usług. $Z$ powodu tej tendencji najbardziej zaawansowane technologicznie kraje wprowadziły już Bezwarunkowy Dochód Podstawowy (np. Finlandia). To, co dzieje się w najbardziej zaawansowanych krajach, w niedalekiej przyszłości będzie prawdopodobnie występowało w innych krajach uprzemysłowionych. Światowe Forum Ekonomiczne już bierze pod uwagę tego typu scenariusze. Obywatele będą wynagradzani, aby konsumować, nie produkować.

Praca socjalna nie jest wyjątkiem od tej tendencji. Jak wykazałem, w krajach rozwiniętych stosuje się już tzw. social robots (roboty społeczne), pracujące z osobami starszymi i niepełnosprawnymi. Wielkie korporacje inwestują ogromne sumy w rozwijanie interakcji człowiek-komputer oraz interakcji człowiek-robot. „Interakcje” to termin, którego socjologowie użyliby prawdopodobnie tylko do opisania rodzaju relacji występujących między ludźmi. Tymczasem inżynierowie już używają tego określenia do opisania również relacji między ludźmi a maszynami.

Max Weber (2008: 47-48) uważa, że jeśli socjologowie nie są uprawnieni do wyrażania sądów wartościujących lub decydowania o celach innych, wciąż mogą udzielać rad typu technicznego, czyli rad funkcjonalnych, do „działania racjonalno-celowego” (zweck rationales Handeln). W tym duchu poza opisem samej tendencji można stwierdzić, że socjologowie i pracownicy socjalni powinni zacząć współpracować z inżynierami (i odwrotnie), zamiast łudzić się, że świat będzie taki sam, jak kiedyś. Dzisiaj wybór nie dokonuje się pomiędzy kontynuacją pracy w obecnej formie a wprowadzaniem „robotów społecznych” na miejsca pracy. Wybór jest pomiędzy wprowadzaniem „robotów społecznych" na miejsca pracy i współpracą z nimi lub zastępowaniem człowieka przez maszyny. Należy także pamiętać, że ta druga opcja jest częściej wybierana w innych sektorach gospodarki.

Prawdopodobnie praca socjalna jest jednym $\mathrm{z}$ tych sektorów, $\mathrm{w}$ którym ludzie zawsze będą potrzebni, ponieważ sam rozwój zadowalającej interakcji człowieka z człowiekiem jest jej celem. Dlatego też pracownicy socjalni są w lepszej sytuacji niż wielu innych pracowników wokół nich. Niewykluczone, że w pracy socjalnej maszyny będą pełniły jedynie pomocniczą rolę, a nie zastępczą. Mimo to, jeśli naszym przeznaczeniem jest bycie otoczonymi przez roboty, bardziej racjonalnym działaniem pracowników socjalnych byłoby rozpoczęcie współpracy z inżynierami. W ten sposób mogliby im pomóc projektować maszyny, naprawdę użyteczne dla osób starszych i niepełnosprawnych.

Wśród klientów lub pacjentów pracowników socjalnych są osoby, które mają bardzo ograniczony lub specyficzny sposób komunikacji i interakcji. Roboty i komputery muszą „Zrozumieć" te osoby. Nikt lepiej niż socjologowie, psychologowie i pracownicy socjalni nie może pomóc inżynierom w rozwijaniu sprzętu i oprogramowania potrzebnego do wykonania tego zadania. 


\section{Bibliografia}

Arkin R. (1998). Behavior-Based Robotics. The MIT Press, Cambridge.

Blackford R. (2012). Robots and reality: A reply to Robert Sparrow. „Ethics and Information Technology",14 (1): 41-51.

Darling K. (2012). Extending Legal Rights to Social Robots. Paper presented at We Robot Conference. University of Miami, April 23, http://ssrn.com/abstract=2044797 or http:// dx.doi.org/10.2139/ssrn.2044797(dostęp: 19.11.2015).

Daerden F., Lefeber D. (2014). Pneumatic Artificial Muscles: Actuators for Robotics and Automation. Vrije Universiteit Brussel, lucy.vub.ac.be (dostęp: 27.02.2015).

Desai J.P., Dudek G., Khatib O., Kumar V. (red.) (2013). Experimental Robotics. Springer, Heidelberg.

Flandorfer P. (2012). Population ageing and socially assistive robots for elderly persons: The importance of sociodemographic factors for user acceptance. „International Journal of Population”. Research Article ID 829835 (13 pages). http://dx.doi.org/10.1155/2012/829835 (accessed: 19.11.2015).

Floreano D., Mattiussi C.(2008). Bio-Inspired Artificial Intelligence. Theories, Methods, and Technologies. The MIT Press, Cambridge.

GeShuzhi S., Khatib O., Cabibihan J.J., Simmonsi R., Williams M.-A. (red.) (2012). Social Robotics. Fourth International Conference Proceedings. Springer, Heidelberg.

GeShuzhi S., Li H., Cabibihan J.J., Yeow K.T.(red.) (2010). Social Robotics. Second International Conference Proceedings. Springer, Heidelberg.

Haddadin S. (2014). Towards Safe Robots. Approaching Asimov's 1st Law. Springer, Heidelberg. Hermann G., Pearson M.J., Lenz A., Bremner P., Spiersi A., Leonards U. (red.) (2012). Social Robotics. Fifth International Conference Proceedings. Springer, Heidelberg.

KandaT., Ishiguro H. (2013). Human-Robot Interaction in Social Robotics. CRC Press, Boca Raton.

Liu Y., Sun D. (2012). Biological Inspired Robotics. CRC Press, Boca Raton.

Moyle W., Cooke M., Beattie E., Jones C., Klein B., Cook G., Gray C. (2013). Exploring the effect of companion robots on emotional expression in older people with dementia: A pilot RCT. „Journal of Gerontological Nursing”, 39 (5): 46-53.

Mutlu B., Bartneck Ch., Ham J., Evers V., Kanda T. (red.) (2011). Social Robotics. Third International Conference Proceedings. Springer, Heidelberg.

Odetti L., Anerdi G., Barbieri M.P., Mazzei D., Rizza E., Dario P., Rodriguezi G., Micera S. (2007). Preliminary experiments on the acceptability of animaloid companion robots by older people with early dementia, w: Conference proceedings: Annual International Conference of the IEEE Engineering in Medicine and Biology Society: 1816-1819.

Paprotny I., Bergbreiter S. (2014). Small-Scale Robotics: From Nano-to-Millimeter-Sized Robotic Systems and Applications. Springer, Heidelberg.

Schank R.C., Abelson R.P. (1975). Scripts, Plans, and Knowledge. Proceedings of the 4th International Joint Conference on Artificial Intelligence, Volume 1:151-157. 
Shin D., Yeh X., Naritai T., Khatib O .(2013). Motor vs. Brake: Comparative Studies on Performance and Safety in Hybrid Actuations, w: Desai J.P. i in.(red.), Experimental Robotics. Springer, Heidelberg.

Siciliano B. (2013). Foreword, w: Desai J.P. i in. (red.), Experimental Robotics. Springer, Heidelberg. Sparrow R. (2002). The march of the robot dogs. „Ethics and Information Technology”, 4(4): 305-318.

Wang L., Tan Ch.K., Chew M.Ch. (2006). Evolutionary Robotics: From Algorithms to Implementations. World Scientific Publishing, Singapore.

Weber M. (2008). Max Weber's Complete Writings on Academic and Political Vocations. Algora Publishing, New York.

Złotowski J., Weiss A., Tscheligi M. (2011). Interaction Scenarios for HRI in Public Space, w: Mutlu B. i in.(red.), Social Robotics. Springer, Heidelberg. 